\title{
Hormonal regulation of oestrogen and progesterone receptors in cultured bovine endometrial cells
}

\author{
C. W. Xiao and A. K. Goff* \\ Centre de Recherche en Reproduction Animale, Faculté de Médecine Vétérinaire, Université de Montréal, 3200 Rue Sicotte, \\ St-Hyacinthe, Quebec J2S 7C6, Canada
}

\begin{abstract}
Changes in the number of progesterone and oestradiol receptors in the endometrium are thought to play a role in the induction of luteolysis. The effect of oestradiol and progesterone on the regulation of their receptors in cultured bovine uterine epithelial and stromal cells was examined to determine the mechanisms involved in this process. Cells were obtained from cows at days 1-3 of the oestrous cycle and were cultured for 4 or 8 days in medium alone (RPMI medium $+5 \%(\mathrm{v} / \mathrm{v})$ charcoal-dextran stripped newborn calf serum) or with oestradiol, progesterone or oestradiol and progesterone. At the end of culture, receptor binding was measured by saturation analysis. Specific binding of both

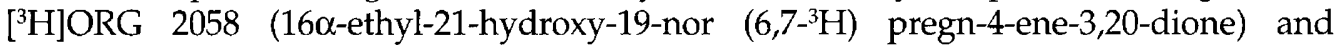
$\left[{ }^{3} \mathrm{H}\right]$ oestradiol to epithelial and stromal cells showed high affinities $\left(K_{\mathrm{d}}=1.1 \times 10^{-9}\right.$ and $6 \times$ $10^{-10} \mathrm{~mol} \mathrm{l}^{-1}$, respectively, for progesterone receptors; $K_{\mathrm{d}}=5.5 \times 10^{-9}$ and $7 \times 10^{-10} \mathrm{~mol} \mathrm{l}^{-1}$, respectively, for oestradiol receptors). In the stromal cells, oestradiol $\left(0.1-10 \mathrm{nmol} \mathrm{l}^{-1}\right)$ increased the number of oestradiol receptors from $0.21 \pm 0.06$ to $0.70 \pm 0.058 \mathrm{fmol} \mathrm{pg}^{-1}$ DNA and the number of progesterone receptors from $1.4 \pm 0.83$ to $6.6 \pm 0.70 \mathrm{fmol}^{\mathrm{N}} \mathrm{g}^{-1}$ DNA in a dose-dependent manner after 4 days of culture $(P<0.01)$. After culture for 8 days, the stimulatory effect of oestradiol increased. Progesterone $\left(50 \mathrm{nmol} \mathrm{l}^{-1}\right)$ had no effect on the number of oestradiol or progesterone receptors $(P>0.05)$. However, progesterone inhibited the stimulatory effect of oestradiol. In epithelial cells, the lower concentrations of oestradiol $\left(0.1\right.$ and $\left.1 \mathrm{nmol} \mathrm{l}^{-1}\right)$ stimulated the number of progesterone receptors $(P=0.05)$ after 4 days culture, whereas the highest concentration of oestradiol $\left(10 \mathrm{nmol} \mathrm{l}^{-1}\right)$, progesterone $\left(50 \mathrm{nmol} \mathrm{l}^{-1}\right)$ and progesterone $\left(50 \mathrm{nmol} \mathrm{l}^{-1}\right)$ plus oestradiol $(1$ nmol $\mathrm{l}^{-1}$ ) had no effect. After culture for 8 days, the stimulatory effect of oestradiol decreased. In contrast to progesterone receptors, the number of oestradiol receptors increased with oestradiol concentration $(P<0.01)$. These data show that the number of progesterone receptors was higher in the stromal cells than in epithelial cells, whereas the number of oestradiol receptors was higher in the epithelial cells than in stromal cells. Oestradiol upregulates its own receptor and increases the number of progesterone receptors in both cell types in vitro, whereas progesterone has little effect, but inhibits the effects of oestradiol on progesterone receptors.
\end{abstract}

\section{Introduction}

The bovine endometrium is a highly sensitive target organ for ovarian steroid hormones (Boos et al., 1996). In ruminants, the uterine epithelium, stroma and myometrium all contain receptors for progesterone and oestrogen (Wathes and Hamon, 1993; Boos et al., 1996). The number of endometrial receptors determines the sensitivity of the uterus to steroid stimulation and the receptors are themselves regulated by steroid hormones. The number of oestradiol and progesterone receptors changes throughout the oestrous cycle in response to changes in circulating steroid hormone concentrations (Boos et

* Correspondence.

Received 23 April 1998. al., 1996). Receptors are present in the highest concentrations at postpartum anoestrus, oestrus and during the follicular phase of the oestrous cycle, when plasma progesterone concentrations are low (Vesanen et al., 1988; Vesanan et al., 1991). During the luteal phase of the oestrous cycle, when progesterone production by the corpus luteum increases, oestradiol and progesterone receptor concentrations decrease in the endometrium (Findlay et al., 1982; Zelinski et al., 1982; Vesanen et al., 1988; Vesanan et al., 1991; Salamonsen et al., 1992; Boos et al., 1996). It is generally accepted that progesterone and oestradiol exert opposing effects on steroid receptors in the uterus. Oestradiol increases the number of oestradiol and progesterone receptors and progesterone decreases the number of these receptors (Katzenellenbogen, 1980; Leavitt et al., 1983; Clark et al., 1985). 
The timing and initiation of luteolysis are critical for the normal oestrous cycle in ruminant animals (Lamming and Mann, 1995). Changes in the number of progesterone and oestradiol receptors are thought to play a role in luteolysis in sheep and cattle (McCracken $e t$ al., 1984; Spencer et al., 1995; Wathes and Lamming, 1995). The number of uterine progesterone and oestradiol receptors may influence uterine PGF $_{2 \alpha}$ secretion, and thus the lifespan of the corpus luteum during the oestrous cycle (Zollers et al., 1993) and early pregnancy (Spencer and Bazer, 1995). The duration of the luteal phase is controlled by the time of initiation and duration of exposure to progesterone. Early administration of progesterone shortens the interoestrus interval in ewes and cows, and blocking progesterone stimulation using a progesterone receptor antagonist delays luteolysis in sheep (Woody and Ginther, 1968; Ginther, 1970; Ottobre et al., 1980; Garrett et al., 1988). Owing to the inhibitory effect of progesterone on progesterone and oestradiol receptors, extended exposure of the uterus to progesterone downregulates progesterone receptors and desensitizes the uterus to progesterone. As the inhibitory effect of progesterone decreases, the number of oestradiol receptors increases in the presence of oestrogen and thus increases the sensitivity of the uterus to oestrogen. In addition, the number of oxytocin receptors in the endometrium is regulated by progesterone and oestrogen; progesterone inhibits oxytocin receptors and oestrogen enhances oxytocin receptors (Hixon and Flint, 1987; Spencer $e$ t al., 1995; Spencer et al., 1996). Therefore, downregulation of progesterone increases oxytocin receptors and the sensitivity of the endometrium to oxytocin stimulation, which induces

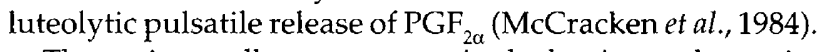

The various cell types present in the bovine endometrium exhibit significantly different patterns of oestrogen and progesterone receptor immunoreactivities during the oestrous cycle (Boos et al., 1996). In sheep, oestradiol receptor distribution varies according to the cell type, tissue compartment (caruncular or intercaruncular endometrium) and the location of the particular cell type within that compartment (Salamonsen et al., 1992; Spencer et al., 1996). This suggests that different cell types within the uterus respond differently to identical hormonal stimuli (Boos et al., 1996).

Modulation of progesterone and oestrogen receptors by steroid hormones in different endometrial cell populations is not completely understood due to the complexity of the interactions involved. In this study, endometrial stromal and epithelial cells in primary culture were used to investigate hormonal regulation of oestradiol and progesterone receptors in the bovine uterus.

\section{Materials and Methods}

\section{Chemicals and reagents}

Tissue culture medium (RPMI 1640), Hank's buffered saline solution (HBSS, calcium and magnesium free), newborn calf serum (NBCS), antibiotics and trypan blue were purchased from GIBCO (Grand Island, NY). Collagenase
(Type II), trypsin (Type III, from bovine pancreas), DNase I (Type I, from bovine pancreas), gentamicin, calf thymus DNA, Hoechst No. 33258, BSA, oestradiol and progesterone were purchased from Sigma Chemical Co. (St Louis, MO). Stock solutions of oestradiol and progesterone were prepared by dissolving the steroids in ethanol. Matrigel was obtained from VWR Canlab (Ontario). Bio-Rad protein assay-dye reagent concentrate was obtained from Bio-Rad Laboratories (Hercules, CA). $\left[2,4,6,7-{ }^{3} \mathrm{H}\right]$ oestradiol $(83.0 \mathrm{Ci}$ $\mathrm{mmol}^{-1}$ ), [ ${ }^{3} \mathrm{H}$ ]ORG 2058 (16 $\alpha$-ethyl-21-hydroxy-19-nor [6,7${ }^{3} \mathrm{H}$ ] pregn-4-ene-3,20-dione; $49.0 \mathrm{Ci} \mathrm{mmol}^{-1}$ ) and unlabelled ORG were purchased from Amersham Life Science (Oakville, Ontario). Diethylstilboestrol was obtained from ICN Biochemicals Inc. (Aurora, $\mathrm{OH}$ ).

\section{Preparation and culture of cells}

Uteri from cows at days 1-3 of the oestrous cycle (ovaries with a corpus haemorrhagicum) were collected at an abattoir and transported on ice to the laboratory. The presence of a corpus haemorrhagicum in the experimental tissue allowed accurate estimation of the stage of the oestrous cycle, thus reducing variability among experiments. In addition, the tissue was taken before exposure to high concentrations of progesterone, allowing the long-term effects of progesterone to be studied in vitro. Endometrial epithelial and stromal cells were separated by modifying the procedure of Fortier et al. (1988). Briefly, the two uterine horns were placed in sterile HBSS containing 100 iu penicillin, $100 \mu \mathrm{g}$ streptomycin $\mathrm{ml}^{-\mathrm{f}}$ and $0.25 \mu \mathrm{g}$ amphotericin $\mathrm{ml}^{-1}$. The myometrial layers were dissected and each uterine horn was then everted to expose the epithelium. The everted horns were first digested for $2 \mathrm{~h}$ in HBSS with $0.3 \%(\mathrm{w} / \mathrm{v})$ trypsin at room temperature to obtain epithelial cells. At the end of the incubation, the digested horns were scraped lightly with forceps, and washed twice in HBSS. The tissue was further digested to obtain stromal cells by incubating in HBSS with $0.064 \%(\mathrm{w} / \mathrm{v})$ trypsin III, $0.064 \%(\mathrm{w} / \mathrm{v})$ collagenase II and $0.032 \%(\mathrm{w} / \mathrm{v})$ DNase I for $45 \mathrm{~min}$ at $37^{\circ} \mathrm{C}$. Immediately after each cell suspension was collected, $10 \%$ NBCS was added to inhibit the trypsin. For epithelial cells, the cell suspension was centrifuged at $60 \mathrm{~g}$ for $5 \mathrm{~min}$ and the pellet was then washed three times with HBSS. For further purification, the epithelial cell pellet was suspended in $20 \mathrm{ml}$ RPMI medium supplemented with 5\% NBCS and $50 \mu \mathrm{g}$ gentamicin $\mathrm{ml}^{-1}$, plated onto $100 \mathrm{~mm} \times 20 \mathrm{~mm}$ Nunclon Petri dishes (Grand Island, NY) and then incubated at $37^{\circ} \mathrm{C}$ with $5 \%$ $\mathrm{CO}_{2}$ and $95 \%$ air for $3 \mathrm{~h}$. At the end of incubation, contaminating stromal cells adhered to the dish and the floating epithelial cells were collected. After cell counting and viability determination by trypan blue exclusion, $2.5 \times 10^{6}$ cells per dish were plated onto Matrigel-coated $100 \mathrm{~mm} \times 20 \mathrm{~mm}$ dishes. Since the epithelial cells only attached to the plates after approximately $48 \mathrm{~h}$, they were cultured for a further 4 days at $37^{\circ} \mathrm{C}$ in humidified air $\left(5 \% \mathrm{CO}_{2}\right)$ in RPMI- 1640 medium containing $5 \%$ NBCS depleted of steroids by dextran-charcoal extraction. The cells were then cultured for 4 or 8 days in the presence or absence of various concentrations of oestrogen and progesterone. The medium was changed every 2 days.

For stromal cells, the cell suspension was centrifuged at 
$60 \mathrm{~g}$ for $5 \mathrm{~min}$ to remove clumps of cells and then the supernatant was centrifuged at $1000 \mathrm{~g}$ for $10 \mathrm{~min}$. The pelleted cells were washed twice with HBSS. The stromal cell suspension was plated onto dishes at a concentration of $1 \times 10^{7}$ cells per dish and after a $3 \mathrm{~h}$ incubation, the floating cells were washed away by gentle pipetting. The attached stromal cells were then cultured in RPMI-1640 medium containing 5\% NBCS depleted of steroids by dextran-charcoal extraction, in the presence or absence of various concentrations of oestrogen and progesterone at $37^{\circ} \mathrm{C}$ in humidified air $\left(5 \% \mathrm{CO}_{2}\right)$ for 4 or 8 days. The medium was changed every 2 days.

The homogeneity of the cell populations was examined by immunocytochemistry. Epithelial cell contamination of stromal cells was about $3 \%$ and stromal cell contamination of epithelial cells was less than 1\% (Xiao and Goff, 1998). The cells were approximately $40 \%$ confluent at the time of treatment and were $70-80 \%$ and $100 \%$ confluent on days 4 and 8 , respectively.

\section{Progesterone and oestrogen receptor assays}

After treatment with different hormonal regimens for 4 or 8 days, uterine cells were rinsed with HBSS and detached from

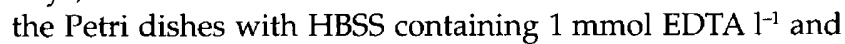
gentle scraping with a rubber scraper. The cells were pelleted at $500 \mathrm{~g}$ for $5 \mathrm{~min}$ and resuspended in $250 \mu \mathrm{l}$ HED buffer ( 20

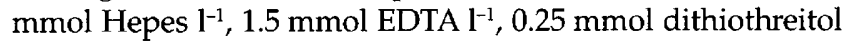
$\mathrm{l}^{-1}, \mathrm{pH}$ 7.4). After removal of $5 \mu \mathrm{l}$ cell suspension for DNA measurement, the remaining cell suspension was sonicated and pelleted at $15000 \mathrm{~g}$ for $10 \mathrm{~min}$. The supernatant was collected and the pellet was treated twice with $150 \mu \mathrm{l}$ extraction buffer $\left(0.6 \mathrm{~mol} \mathrm{KCl}^{-1}\right.$ in HED) on ice for $20 \mathrm{~min}$. This treatment extracted any remaining nuclear material. At the end of the extraction, the cell debris was separated by centrifugation at $15000 \mathrm{~g}$ for $10 \mathrm{~min}$. The supernatant was combined with the initial supernatant collected after sonication and was used for oestrogen and progesterone receptor measurements. The protein concentration was determined using the method of Bradford (1976) (Bio-Rad Laboratories, CA). The DNA content was measured by the bisbenzimide fluorescent dye method of Labarca and Paigen (1980). Calf thymus DNA was used as the standard at concentrations of $4,8,16,32,64,128$ and $250 \mathrm{ng} \mathrm{ml}^{-1}$.

Saturation analysis of oestradiol and progesterone receptors in primary cultures of uterine endometrial cells was performed in the presence of $1 \mathrm{nmol}$ oestradiol $\mathbf{1}^{-1}$ for 4 days. The supernatants were incubated with $0.5-20 \mathrm{nmol}$ $\left[{ }^{3} \mathrm{H}\right]$ ORG $2058 \mathrm{l}^{-1}$ or $0.5-10 \mathrm{nmol} \quad\left[{ }^{3} \mathrm{H}\right]$ oestradiol $\mathrm{l}^{-1}$ for progesterone and oestradiol receptor measurements, respectively. The binding affinities of [ $\left.{ }^{3} \mathrm{H}\right] \mathrm{ORG} 2058$ and $\left[{ }^{3} \mathrm{H}\right]$ oestradiol for cell supernatants were determined using the least squares curve fitting program LIGAND (Munson and Rodbard, 1980). ORG 2058 was used for measurement of progesterone receptors because of its low non-specific binding. Furthermore, in contrast to progesterone, it does not bind to the corticosteroid receptor. The data are presented as saturation and Scatchard curves (Scatchard, 1949).

Supernatants $\left(0.8-1.0 \mathrm{mg} \mathrm{ml}^{-1}\right.$ total protein) were incubated with $10 \mathrm{nmol}\left[{ }^{3} \mathrm{H}\right]$ ORG $2058 \mathrm{1}^{-1}$ in HED buffer with or without a 200-fold excess of unlabelled ORG 2058 at $4^{\circ} \mathrm{C}$ for $2.5-4.0 \mathrm{~h}$ to measure total and non-specific binding, respectively, and to determine the effect of steroid treatment on the number of progesterone receptors. For the oestradiol receptor assay, cell supernatants were incubated with $5 \mathrm{nmol}\left[{ }^{3} \mathrm{H}\right]$ oestradiol $\mathrm{l}^{-1}$ in HED buffer with or without a 200 -fold excess of unlabelled diethylstilboestrol at $4^{\circ} \mathrm{C}$ for $16 \mathrm{~h}$, and then incubated at $30^{\circ} \mathrm{C}$ for $3 \mathrm{~h}$. After incubation, bound and free steroid were separated by adsorption with dextran-coated charcoal (DCC; $0.5 \%(\mathrm{w} / \mathrm{v})$ charcoal and $0.05 \%(\mathrm{w} / \mathrm{v})$ dextran in HED buffer) for $15 \mathrm{~min}$ at $4^{\circ} \mathrm{C}$ as described by Leake and Habib (1987). Specific binding (total minus non-specific binding) values are expressed as femtomole per microgram of DNA.

\section{Statistical analysis}

Each treatment was carried out in triplicate using the cells from one uterus and each experiment was repeated with six different uteri. The data were log transformed where necessary to eliminate heterogeneity of variance. For each cell type, regression analysis was used to describe the effect of dose of oestradiol on the number of receptors, and a $2 \times 2 \times 2$ factorial design (ANOVA) was used to analyse the effects of oestradiol, progesterone and the duration of culture. The ANOVA included the main effects of duration of culture, progesterone treatment, oestradiol treatment and all interactions. Since uterus was nested within an experiment it was included as a random variable in the $F$ test for the effect of experiment. Simple effect comparisons to determine differences between individual means were performed using preplanned orthogonal contrasts. A probability of $P<0.05$ was considered to be statistically significant. The data were analysed using the computer program JMP (SAS Institute Inc., NC).

\section{Results}

\section{Characterization of oestradiol and progesterone receptor binding in endometrial cells}

Specific binding of $\left[{ }^{3} \mathrm{H}\right] \mathrm{ORG} 2058$ and $\left[{ }^{3} \mathrm{H}\right]$ oestradiol by epithelial and stromal cells from bovine uterine endometrium collected at days 1-3 of the oestrous cycle was saturable and showed high affinities (Figs 1 and 2). The progesterone receptors were saturated at 5 and $10 \mathrm{nmol} \mathrm{l}^{-1}$ for epithelial and stromal cells, respectively (Fig. 1a,c). The dissociation constants $\left(K_{\mathrm{d}}\right)$ were $1.1 \mathrm{nmol}^{-1}$ for epithelial cells (Fig. 1b) and $0.6 \mathrm{nmol}^{-1}$ for stromal cells (Fig. 1d). The oestradiol receptors were saturated at $5 \mathrm{nmol} \mathrm{l}^{-1}$ for both epithelial and stromal cells (Fig. 2a,c). The dissociation constants $\left(K_{d}\right)$ were $5.5 \mathrm{nmol} \mathrm{l}^{-1}$ for epithelial cells (Fig. 2b) and $0.7 \mathrm{nmol}^{-1}$ for stromal cells (Fig. 2d).

\section{Effect of oestradiol and progesterone on the number of progesterone receptors in stromal cells}

Oestradiol stimulated the number of progesterone receptors in stromal cells after 4 days of incubation in a linear 

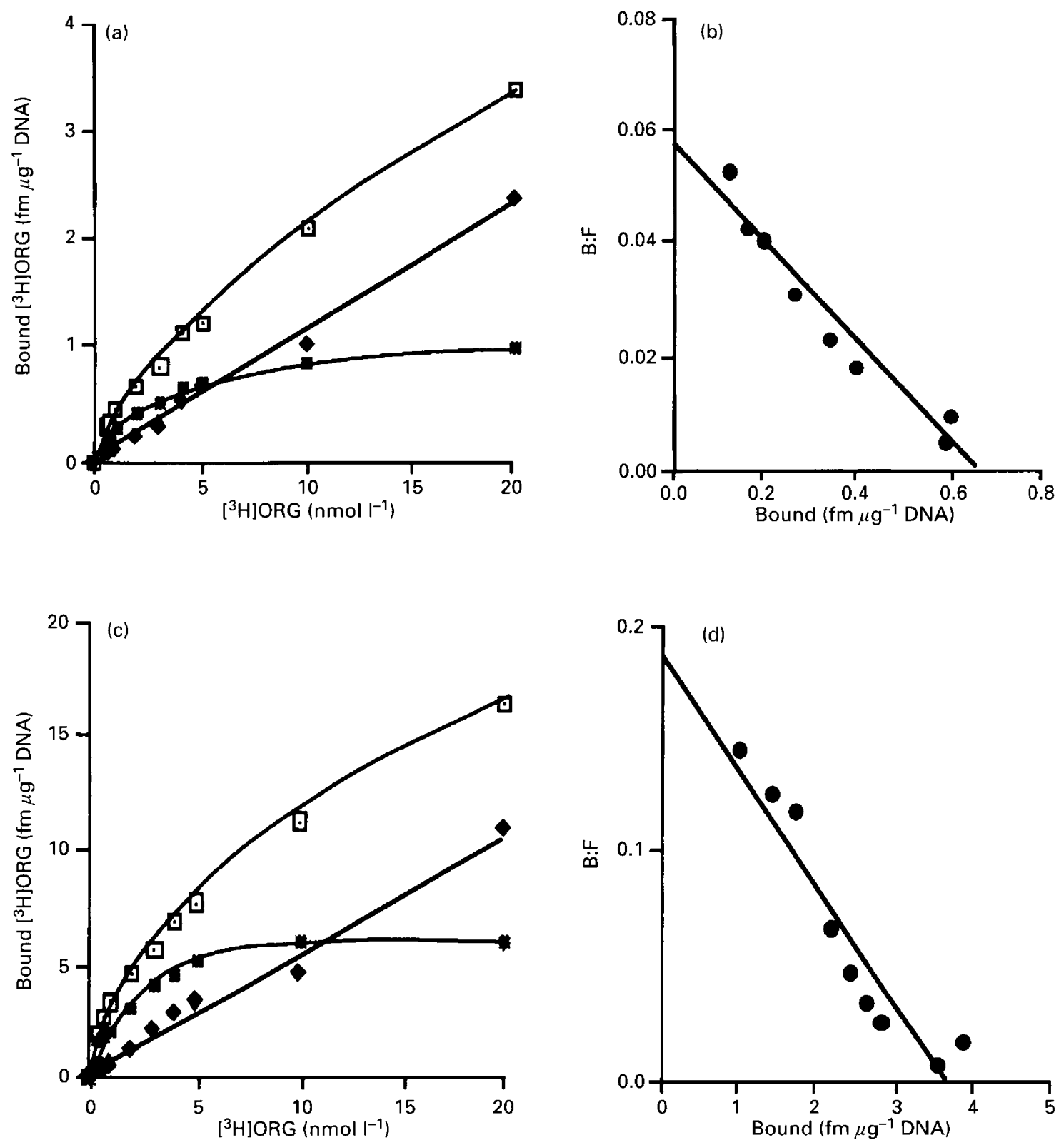

Fig. 1. Saturation analysis of specifically bound [ $\left.{ }^{3} \mathrm{H}\right] \mathrm{ORG} 2058\left(16 \alpha\right.$-ethyl-21-hydroxy-19-nor $\left(6,7-{ }^{3} \mathrm{H}\right)$ pregn-4-ene-3,20dione) to primary cultures of bovine uterine cells. Cells were cultured in RPMI 1640 medium containing $5 \%$ (v/v) newborn calf serum in the presence of $1 \mathrm{nmol}$ oestradiol $\mathrm{I}^{-1}$ for 4 days. The whole cell extracts were treated with $0.5-20 \times 10^{-9}$ mol $\left[{ }^{3} \mathrm{H}\right]$ ORG $2058 \mathrm{l}^{-1}$ with or without a 200 -fold molar excess of unlabelled ORG 2058. Total binding ( - ), non-specific binding $(\downarrow)$ and specific binding $(\boldsymbol{Q})$ by (a) epithelial cells and (c) stromal cells are presented as saturation curves.

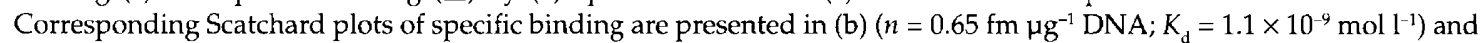

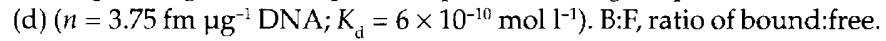

dose-dependent manner $\left(P<0.05, r^{2}=0.12\right)$, with the maximum effect at $10 \mathrm{nmol}^{-1}$ (Fig. 3a). The time-dependent effect of oestrogen and progesterone on the number of progesterone receptors in stromal cells is also shown (Fig. $3 b)$. ANOVA showed an effect of oestradiol $\left(1 \mathrm{nmol} \mathrm{l}^{-1}\right)$ and duration of culture on the number of progesterone receptors in stromal cells $(P<0.01)$. There was a duration of culture $\times$ oestradiol interaction $(P<0.05)$, showing that the response to oestradiol increased with time, and a progesterone $x$ oestradiol interaction $(P<0.001)$ showing that progesterone had no effect but that it inhibited the oestradiol-induced increase in progesterone receptors.

\section{Effect of oestradiol and progesterone on the number of progesterone receptors in epithelial cells}

Oestradiol stimulated the number of progesterone receptors in epithelial cells after 4 days (Fig. 4a). Regression analysis revealed that the best fit regression line was cubic 

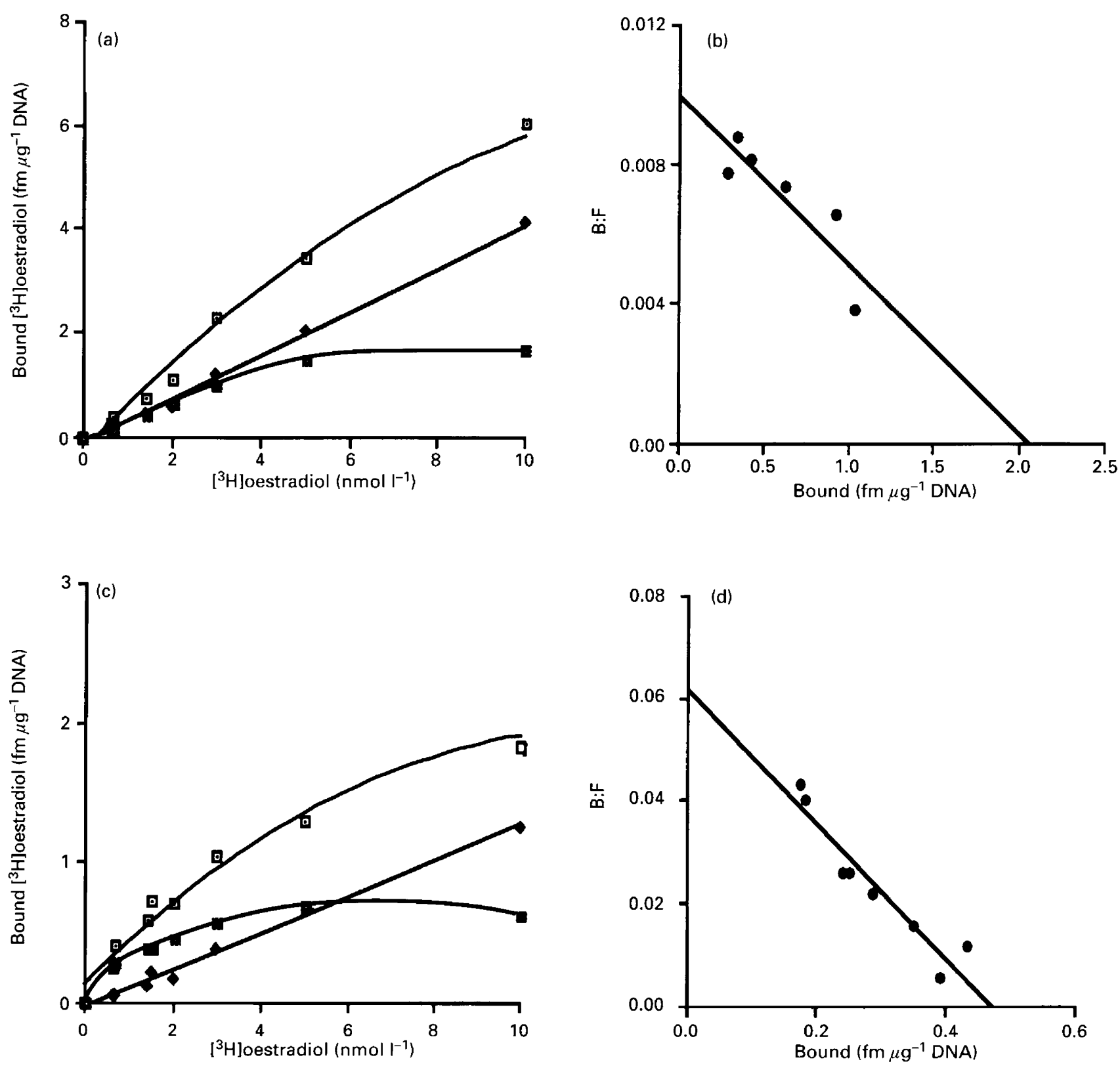

Fig. 2. Saturation analysis of specifically bound $\left[{ }^{3} \mathrm{H}\right]$ oestradiol to primary cultures of bovine uterine cells. Cells were cultured in RPMI 1640 medium containing $5 \%(\mathrm{v} / \mathrm{v})$ new born calf serum in the presence of $1 \mathrm{nmol}$ oestradiol $\mathrm{l}^{-1}$ for 4 days. The whole cell extracts were treated with $0.5-10 \times 10^{-9} \mathrm{~mol}\left[{ }^{3} \mathrm{H}\right]$ oestradiol $1^{-1}$ with or without a 200 -fold molar excess of unlabelled diethylstilboestrol. Total binding ( $\bullet$ ), nonspecific binding $(\checkmark)$ and specific binding $(\square)$ by (a) epithelial cells and (c) stromal cells are presented as saturation curves. Corresponding

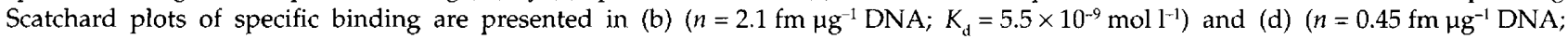
$\left.K_{\mathrm{d}}=7 \times 10^{-10} \mathrm{~mol} \mathrm{l}^{-1}\right)$. B:F, ratio of bound:free.

$\left(P<0.05, r^{2}=0.3\right)$. The lowest concentration of oestradiol used $\left(0.1 \mathrm{nmol} \mathrm{l}^{-1}\right)$ was the most effective $(167 \%$ higher than the control). Progesterone had no effect on the number of progesterone receptors in cultured epithelial cells (Fig. 4b). ANOVA showed an effect of oestradiol $(P=0.05)$ and an oestradiol $\times$ progesterone interaction $(P<0.05)$. Progesterone blocked the oestradiol-induced increase in progesterone receptors at 4 days of culture, and there was no effect of either progesterone or oestradiol after 8 days of culture.

\section{Effect of oestradiol and progesterone on the number of oestradiol receptors in stromal cells}

Oestradiol stimulated the number of oestradiol receptors in stromal cells after 4 days $(P<0.01)$ (Fig. 5a). The effect of oestradiol was dose dependent; a regression analysis showed that the best fit regression line was quadratic $\left(P<0.001, r^{2}=0.22\right)$. The maximum response was observed at $1 \mathrm{nmol} \mathrm{l}^{-1}$, after which the response decreased. The time- 

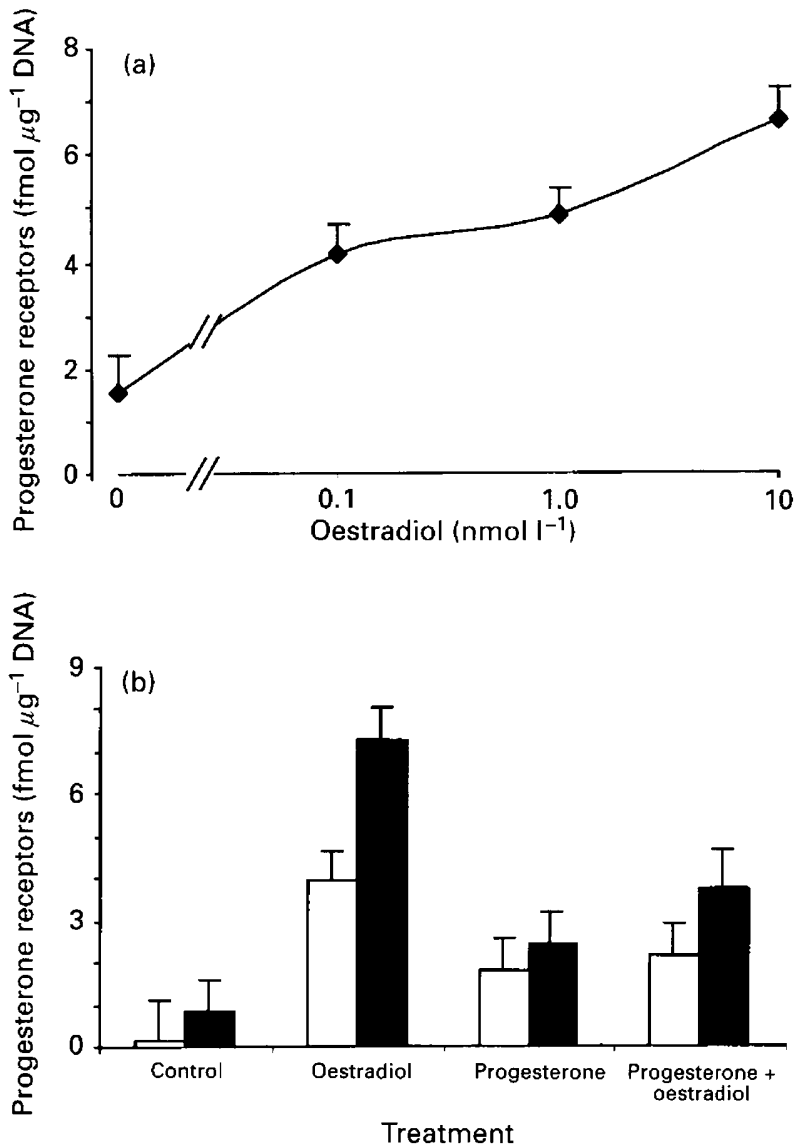

Fig. 3. Time- and dose-dependent effect of oestradiol and progesterone on the number of progesterone receptors in bovine endometrial stromal cells. (a) Primary stromal cells were cultured in RPMI 1640 medium containing 5\% (v/v) newborn calf serum (NBCS) in the presence or absence of oestradiol $\left(0.1,1.0\right.$ or $\left.10 \mathrm{nmol} \mathrm{l}^{-1}\right)$ for 4 days. (b) Primary stromal cells were cultured in RPMI 1640 medium containing $5 \%(\mathrm{v} / \mathrm{v}) \mathrm{NBCS}$ in the presence or absence of $1 \mathrm{nmol}$ oestradiol $\mathrm{l}^{-1}, 50 \mathrm{nmol}$ progesterone $\mathrm{l}^{-1}$, or $50 \mathrm{nmol}$ progesterone $\mathrm{l}^{-1}$ plus $1 \mathrm{nmol}$ oestradiol $\mathrm{l}^{-1}$ for $(\square) 4$ or $(\square) 8$ days. Data represent least square means $\pm \mathrm{SE}$; the minimum detection limit is $0.11 \mathrm{fmol} \mathrm{\mu g}^{-1} \mathrm{DNA}$.

dependent effect of oestradiol and progesterone on the number of oestradiol receptors in stromal cells is also shown (Fig. 5b). Progesterone had no effect on the number of oestradiol receptors. Effects of oestradiol treatment and duration of culture were detected $(P<0.001)$, and there was a significant progesterone $\times$ oestradiol interaction $(P<0.05)$. A duration $\times$ progesterone $\times$ oestradiol interaction was suggested $(P=0.08)$. The number of oestradiol receptors increased markedly in stromal cells between days 4 and 8 of culture $(P>0.001)$. Progesterone had an inhibitory effect on the stimulation of oestradiol receptors by oestradiol after 4 days of culture $(P<0.05)$, but not after 8 days.

\section{Effect of oestradiol and progesterone on the number of oestradiol receptors in epithelial cells}

Oestradiol stimulated the number of oestradiol receptors in epithelial cells in a dose-dependent manner after 4 days
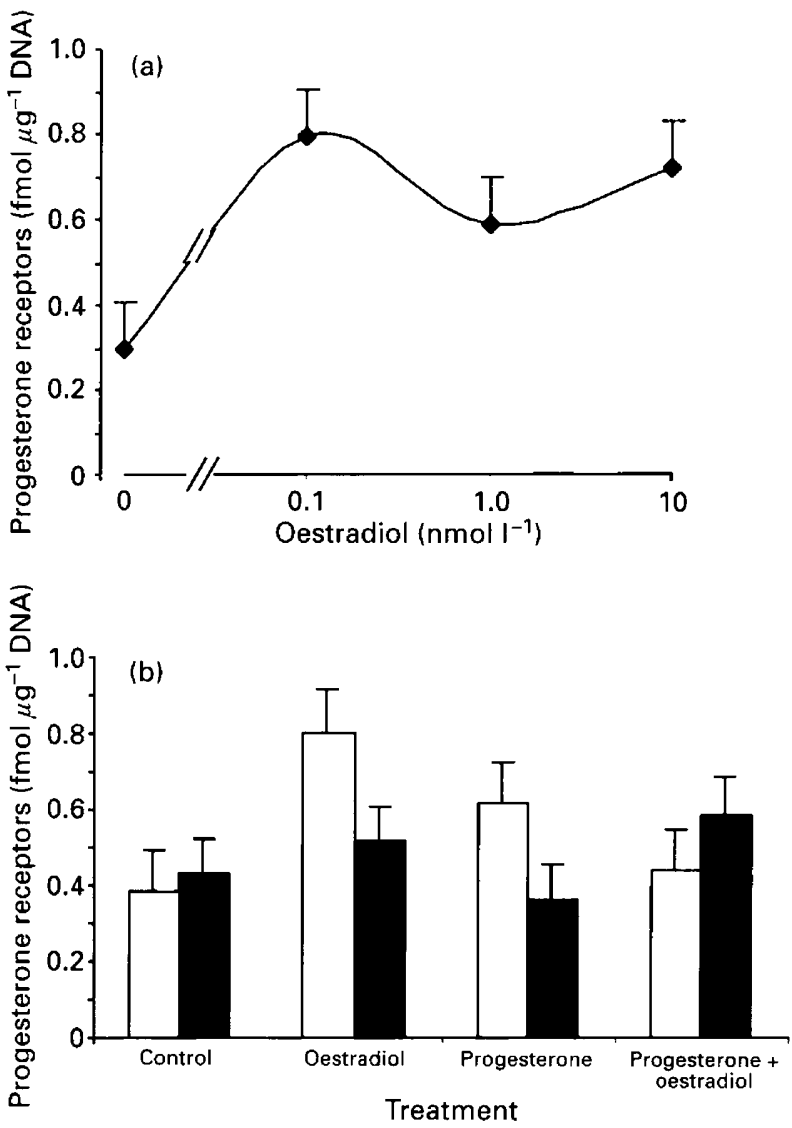

Fig. 4. Time- and dose-dependent effect of oestradiol and progesterone on the number of progesterone receptors in bovine endometrial epithelial cells. (a) Primary epithelial cells were cultured in RPMI 1640 medium containing 5\% (v/v) newborn calf serum (NBCS) in the presence or absence of oestradiol $(0.1,1.0$ or 10 nmol $\mathrm{l}^{-1}$ ) for 4 days. (b) Primary epithelial cells were cultured in RPMI 1640 medium containing $5 \%(\mathrm{v} / \mathrm{v})$ NBCS in the presence or absence of $1 \mathrm{nmol}$ oestradiol $\mathrm{l}^{-1}, 50 \mathrm{nmol}$ progesterone $\mathrm{l}^{-1}$, or $50 \mathrm{nmol}$ progesterone $\mathrm{l}^{-1}$ plus 1 nmol oestradiol $\mathrm{l}^{-1}$ for $(\square) 4$ or $(\square) 8$ days. Data represent least square means $\pm \mathrm{SE}$; the minimum detection limit is $0.11 \mathrm{fmol}_{\mu \mathrm{g}^{-1}} \mathrm{DNA}$.

(Fig. 6a). Regression analysis showed that the best fit regression line was linear $\left(P<0.005, r^{2}=0.51\right)$. The lowest concentration of oestradiol $\left(0.1 \mathrm{nmol}^{-1}\right)$ had no effect on the number of oestradiol receptors in epithelial cells $(P>0.05)$. The number of receptors did not respond to progesterone (50 nmol ${ }^{-1}$ ) (Fig. 6b) and there was no change in the response to oestradiol between 4 and 8 days of culture.

\section{Discussion}

The mechanisms involved in the timing of luteolysis in cattle are not completely understood. Changes in steroid receptors are considered to play an important role in this process (Meyer et al., 1988; Zollers et al., 1993). A culture system in which the cells respond in a similar manner to that observed in vivo is required to investigate the mechanisms involved in luteolysis at the cellular level (Katzenellenbogen, 1980; 

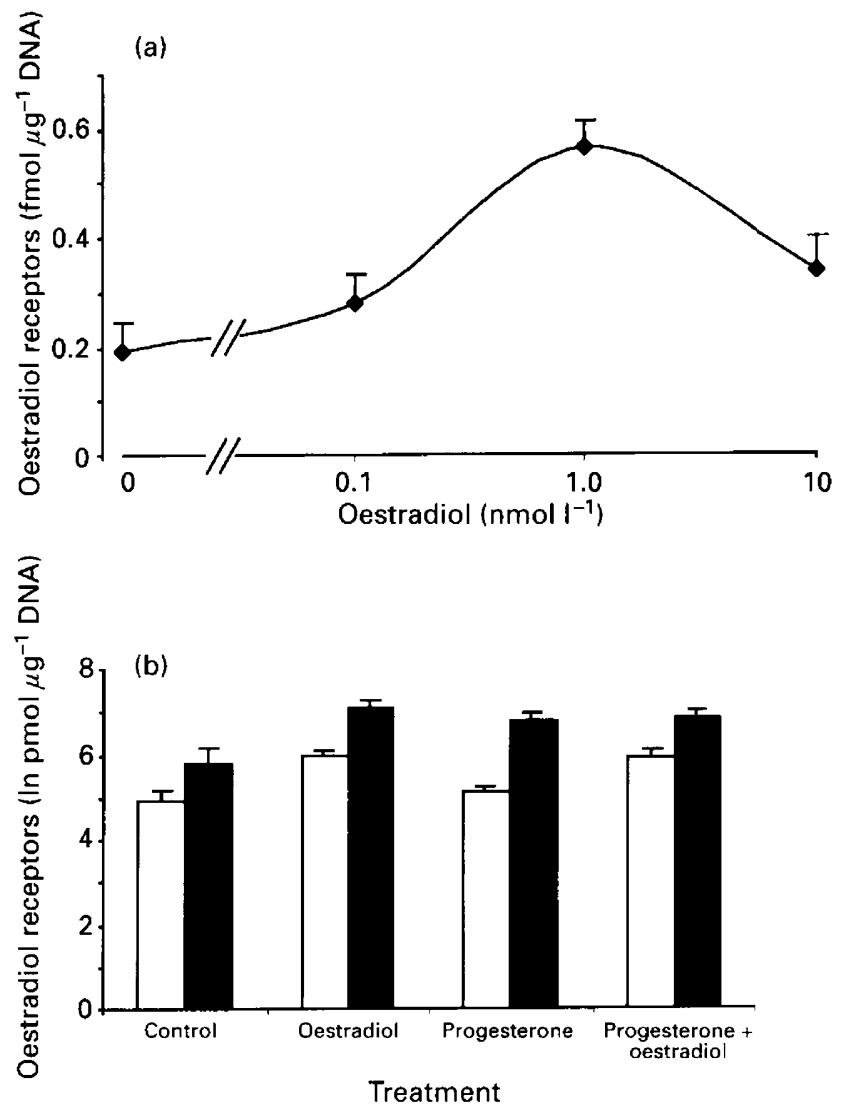

Fig. 5. Time- and dose-dependent effect of oestradiol and progesterone on the number of oestrogen receptors in bovine endometrial stromal cells. (a) Primary stromal cells were cultured in RPMI 1640 medium containing 5\% (v/v) newborn calf serum (NBCS)

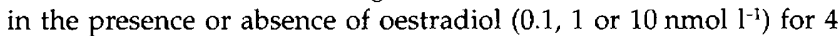
days. (b) Primary stromal cells were cultured in RPMI 1640 medium containing $5 \%(\mathrm{v} / \mathrm{v})$ NBCS in the presence or absence of $1 \mathrm{nmol}$ oestradiol $\mathrm{l}^{-1}, 50 \mathrm{nmol}$ progesterone $\mathrm{l}^{-3}$, or $50 \mathrm{nmol}$ progesterone $\mathrm{l}^{-1}$ plus $1 \mathrm{nmol}$ oestradiol $\mathrm{l}^{-1}$ for $(\square) 4$ or $(\square) 8$ days. The number of receptors is presented on a logarithmic scale in (b). Data represent least square means $\pm \mathrm{SE}$; the minimum detection limit is $0.06 \mathrm{fmol}$ $\mu \mathrm{g}^{-1} \mathrm{DNA}$.

Leavitt et al., 1983; Clark et al., 1985). In this study, a primary cell culture system was used to investigate the effects of steroid hormones on the number of oestrogen and progesterone receptors in epithelial and stromal cells of the bovine endometrium.

Low-speed cell supernatants were used for receptor measurements in this study because in preliminary experiments, no differences were observed in the number of receptors in supernatants separated by ultra-speed or lowspeed centrifugation. This was also demonstrated by Leake and Habib (1987). The results show that both progesterone and oestrogen receptors in cultured bovine endometrial cells are of high affinity $\left(K_{d}=1.1\right.$ and $0.6 \mathrm{nmol} \mathrm{l}^{-1}$, respectively, for progesterone receptors of epithelial and stromal cells; $K_{d}=$ 5.5 and $0.7 \mathrm{nmol} \mathrm{l}^{-1}$, respectively, for oestradiol receptors of epithelial and stromal cells). These values are similar to the affinities of oestradiol and progesterone receptors in
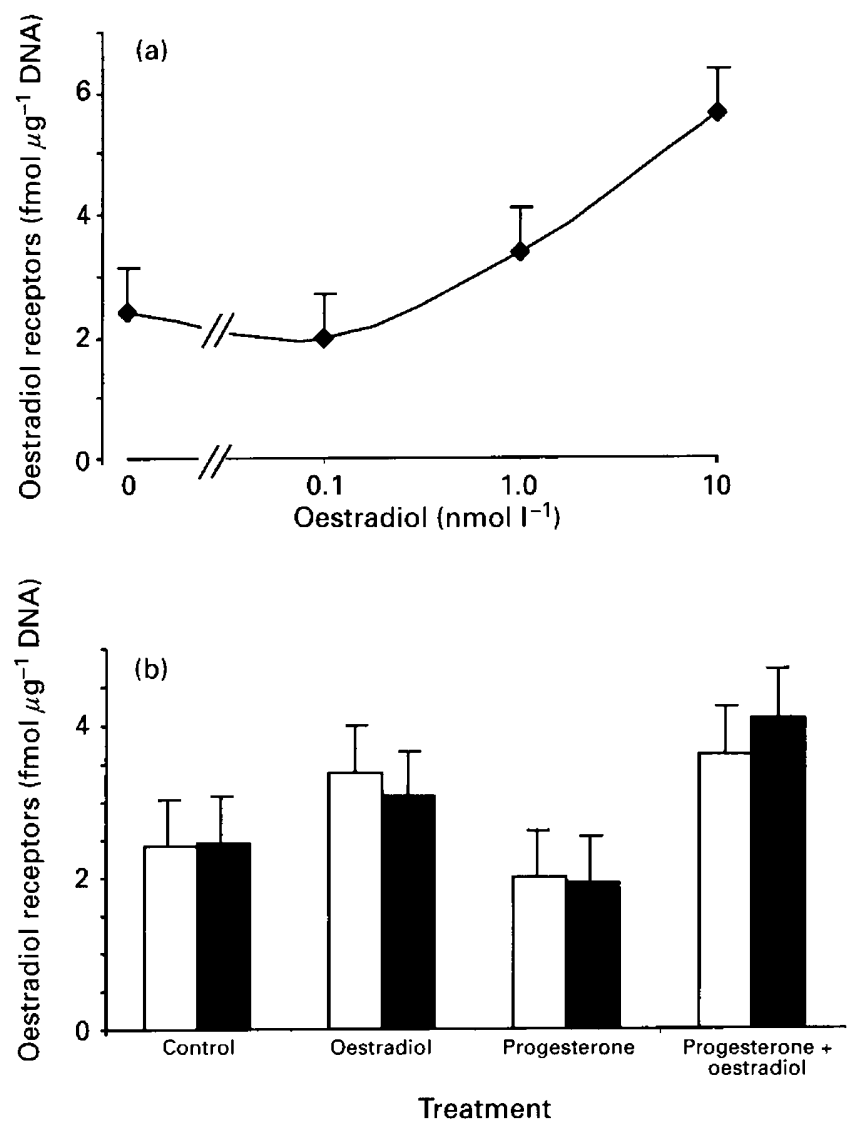

Fig. 6. Time- and dose-dependent effect of oestradiol and progesterone on the number of oestrogen receptors in bovine endometrial epithelial cells. (a) Primary epithelial cells were cultured in RPMI 1640 medium containing $5 \%(\mathrm{v} / \mathrm{v})$ newborn calf serum (NBCS) in the presence or absence of oestradiol $(0.1,1$ or 10 nmol $~^{-1}$ ) for 4 days. (b) Primary epithelial cells were cultured in RPMI 1640 medium containing 5\% (v/v) NBCS in the presence or absence of $1 \mathrm{nmol}$ oestradiol $\mathrm{l}^{-1}, 50 \mathrm{nmol}$ progesterone $\mathrm{l}^{-1}$, or $50 \mathrm{nmol}$ progesterone $\mathrm{l}^{-1}$ plus 1 nmol oestradiol $\mathrm{l}^{-1}$ for $(\square) 4$ or $(\square) 8$ days. Data represent least square means $\pm \mathrm{SE}$; the minimum detection limit

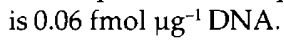

endometrial tissue reported by others. Vesanen et al. (1988) reported that the $K_{d}$ values of oestradiol receptors in bovine endometrial tissue at different stages of the oestrous cycle ranged from 0.26 to $2.5 \mathrm{nmol} \mathrm{l}^{-1}$ and that of progesterone receptors from 0.14 to $0.17 \mathrm{nmol} \mathrm{l}^{-1}$. Meyer et al. (1988) reported a $K_{d}$ value of $2.6 \mathrm{nmol} \mathrm{I}^{-1}$ for endometrial cytosolic progesterone receptors in cattle. In cultured uterine epithelial cells of immature rats, the $K_{d}$ values of cytosolic and nuclear oestradiol receptors were 0.56 and $0.27 \mathrm{nmol} \mathrm{l}^{-1}$, respectively; and those of stromal cells were 0.42 and $0.32 \mathrm{nmol} \mathrm{l}^{-1}$, respectively (McCormack and Glasser, 1980). In the present study, oestradiol and progesterone receptors were detectable in the primary culture system used and their affinities approximate the values reported previously for endometrial tissues.

Two forms have been reported for both the oestradiol and the progesterone receptor. Forms $\mathrm{A}$ and $\mathrm{B}$ of the progesterone 
receptor are present in human endometrium (Tseng and $\mathrm{Zhu}$, 1997). The oestradiol receptor exists in the classical $\alpha$ form and the more recently discovered $\beta$ form (Kuiper et al., (1996). The $\beta$ form is present in the bovine endometrium (Rosenfeld et al., 1998) and may be involved in uterine function. The different forms of the oestradiol and progesterone receptors are likely to be present in the cell preparations used in the present study. However, no attempt was made to determine which form of each of the receptors changes in response to steroid treatment.

The basal concentration of progesterone receptors was higher in stromal cells than in epithelial cells. This is in agreement with what is observed in the endometrium during the early luteal phase in cows (Boos et al., 1996). In contrast, the basal concentration of oestradiol receptors was higher in epithelial cells than in stromal cells, whereas in cattle and ovariectomized sheep, the number of oestradiol receptors was higher in the stromal cells (Ing and Tornesi, 1997). This may be related to the stage of the cycle at which the investigation was conducted, since receptor numbers change during the oestrous cycle (Wathes and Hamon, 1993; Boos et al., 1996). In addition, luminal and glandular epithelial cells were not separated in the present study and it is possible that there are differences between these two cell types.

Progesterone and oestradiol receptor concentrations in the endometrium are highest at oestrus and during the follicular phase of the oestrous cycle when endogenous oestradiol is high (Findlay et al., 1982; Zelinski et al., 1982; Vesanen et al., 1988; Vesanan et al., 1991; Salamonsen et al., 1992; Boos et al., 1996). This is probably due to upregulation of these receptors by oestradiol. In ovariectomized ewes, oestradiol treatment increased the number of progesterone and oestradiol receptors in both epithelial and stromal cells (Wathes et al., 1996; Ing and Tornesi, 1997). Oestradiol also induced synthesis of endometrial progesterone receptors in vitro and in vivo in rats (Kassis et al., 1984) and sheep (Zelinski et al., 1980). In the present study, oestradiol increased progesterone and oestradiol receptor concentrations in a dose- and time-dependent manner in both cell types. This is in agreement with the observations in vivo. Although oestradiol has been shown to upregulate progesterone receptors in several cell culture systems, this is the first report of upregulation of oestradiol receptors by oestradiol in vitro. Furthermore, the effect of oestradiol was more pronounced in stromal cells than in epithelial cells. This is similar to data from ovariectomized ewes, in which oestradiol treatment caused a greater increase in the number of oestradiol receptors in the stroma than in the luminal epithelium, and the response in the stromal cells appeared earlier and was more prolonged than in the other cell type (Ing and Tornesi, 1997). In the present study, oestradiol stimulation of progesterone and oestradiol receptor concentrations also increased with time in the stromal cells, whereas it diminished during extended culture in the epithelial cells. This is consistent with the observation of Inaba et al. (1988) that the number of progesterone receptors in epithelial cells decreases between days 4 and 8 of oestradiol treatment, while that in stromal cells remains high. This suggests that oestradiol stimulation of receptors differs between the two cell types.
In contrast to the stimulatory action of oestradiol, progesterone inhibits both oestradiol and progesterone receptors (Katzenellenbogen, 1980; Leavitt et al., 1983; Clark et al., 1985; Sumida et al., 1988). This inhibitory effect is probably responsible for the decrease in endometrial receptors by the midluteal phase in cows (Meyer et al., 1988) and ewes (Miller et al., 1977). The results of the present study suggest that progesterone is unable to decrease the number of progesterone and oestradiol receptors below the basal concentrations in untreated isolated cells. It is possible that the concentration of progesterone used (close to the highest concentration observed in peripheral plasma) was not high enough to exert an inhibitory effect in vitro, or that an interaction between the different cell types is necessary for a normal response. Wathes et al. (1996) reported differences between ovariectomized steroid-treated ewes and normal animals; progesterone treatment did not reduce oestradiol receptor concentrations in ovariectomized ewes as was observed in cyclic ewes. It was suggested that ovarian factors other than progesterone and oestradiol are involved in oestradiol receptor regulation. Thus, other factors (such as growth factors and cytokines) may also have a role in receptor regulation in isolated cells.

Although progesterone did not inhibit the number of receptors, it inhibited the stimulatory effect of oestradiol on progesterone receptors in both cell types and on oestradiol receptors in stromal cells. This is in agreement with studies in vivo in ovariectomized ewes, in which progesterone inhibited the increase in the number of progesterone receptors induced by oestradiol treatment (Stone et al., 1978; Wathes et al., 1996). The concentration of oestradiol used in the present study was much higher than that in the peripheral plasma. However, the effect of progesterone was still apparent, which suggests that the ratio of progesterone to oestradiol is not important. This is in agreement with a study in guinea-pig fetuses, in which even a large excess of oestradiol did not increase the number of progesterone receptors as long as progesterone was present (Sumida and Pasqualini, 1979). It is not clear why progesterone did not inhibit oestradiol stimulation of oestradiol receptors in epithelial cells. There may be a difference in receptor regulation in the two cell types, or downregulation of oestradiol receptors in epithelial cells may be mediated by the stromal cells as suggested by Wathes et al. (1996).

In conclusion, this is the first report of the effect of steroid hormones on the number of progesterone and oestradiol receptors in primary cell cultures of bovine uterine endometrial cells. Oestradiol increased the number of progesterone and oestradiol receptors in both cell types. Progesterone had no effect on the number of receptors, but inhibited the oestradiol-induced increase in progesterone receptors in both cell types. These results support the hypothesis that an interaction among cell types is necessary for the normal function of epithelial cells. Therefore, the isolated cell model system used in this study will be very useful for investigation of the effect of steroid hormones and cell type interactions on endometrial function in cows.

This work was supported by grants from NSERC and FCAR Canada. 


\section{References}

Boos A, Meyer W, Schwarz R and Grunert E (1996) Immunohistochemical assessment of oestrogen receptor and progesterone receptor distribution in biopsy samples of the bovine endometrium collected throughout the oestrous cycle Animal Reproduction Science 44 11-21

Bradford MM (1976) A rapid and sensitive method for the quantitation of microgram quantities of protein utilizing the principle of protein-dye binding Analytical Biochemistry 72 248-254

Clark JH, Scrader WT and O'Malley BW (1985) Mechanisms of steroid hormone action. In Textbook of Endocrinology pp 33-75 Eds JD Witson and DW Fortec. Saunders, Philadelphia

Findlay JK, Clarke IJ, Swaney J, Colvin N and Doughton B (1982) Oestrogen receptors and protein synthesis in caruncular and intercaruncular endometrium of sheep before implantation Journal of Reproduction and Fertility 64 329-339

Fortier MA, Guibault LA and Grasso F (1988) Specific properties of epithelial and stromal cells from the endometrium of cows Journal of Reproduction and Fertility 83 239-248

Garrett JE, Geisert RD, Zavy MT, Gries LK, Wettemann RP and Buchanan DS (1988) Effect of exogenous progesterone on prostaglandin F2 $\alpha$ release and the interestrous interval in the bovine Prostaglandins 36 85-96

Ginther OJ (1970) Effect of progesterone on length of estrous cycle in cattle American Journal of Veterinary Research 31 493-496

Hixon JE and Flint APF (1987) Effects of a luteolytic dose of oestradiol benzoate on uterine oxytocin receptor concentrations, phosphoinositide turnover and prostaglandin F-2 $\alpha$ secretion in sheep Journal of Reproduction and Fertility $79457-467$

Inaba T, Wiest WG, Strickler RC and Mori J (1988) Augmentation of the response of mouse uterine epithelial cells to estradiol by uterine stroma Endocrinology 123 1253-1258

Ing NH and Tornesi MB (1997) Estradiol up-regulates estrogen receptor and progesterone receptor gene expression in specific ovine uterine cells Biology of Reproduction 56 1205-1215

Kassis JA, Sakai D, Walent JH and Gorski J (1984) Primary cultures of estrogen-responsive cells from rat uteri: induction of progesterone receptors and a secreted protein Endocrinology 114 1558-1565

Katzenellenbogen BS (1980) Dynamics of steroid hormone receptor action Annual Review of Physiology 42 17-35

Kuiper GGJM, Enmark E, Pelto-Huikko M, Nilsson S and Gustafsson J-Å (1996) Cloning of a novel estrogen receptor expressed in rat prostate and ovary Proceedings of the National Academy of Sciences USA 93 5925-5930

Labarca C and Paigen K (1980) A simple, rapid and sensitive DNA assay procedure Analytical Biochemistry $102344-352$

Lamming GE and Mann GE (1995) Control of endometrial oxytocin receptors and prostaglandin $\mathrm{F} 2 \alpha$ production in cows by progesterone and oestradiol Journal of Reproduction and Fertility 103 69-73

Leake R and Habib F (1987) Steroid hormone receptors: assays and characterization. In Steroid Hormones: A Practical Approach p 69 Eds B Green and RE Leake. IRL Press Ltd, Oxford

Leavitt WW, MacDonald RG and Okulicz WC (1983) Hormonal regulation of estrogen and progesterone receptor systems. In Biochemical Actions of Hormones pp 323-356 Ed. G Litwack. Academic Press, New York

McCormack SA and Glasser SR (1980) Differential response of individual uterine cell types from immature rats treated with estradiol Endocrinology 106 1634-1649

McCracken JA, Schramm W and Okulicz WC (1984) Hormone receptor control of pulsatile secretion of PGF2 $\alpha$ from the ovine uterus during luteolysis and its abrogation in early pregnancy Animal Reproduction Science $731-55$

Meyer HH, Mittermeier T and Schams D (1988) Dynamics of oxytocin, estrogen and progestin receptors in the bovine endometrium during the estrous cycle Acta Endocrinologica 118 96-104

Miller BG, Murphey L and Stone GM (1977) Hormone receptor levels and hormone, RNA and protein metabolism in the genital tract during the oestrous cycle of the ewe Journal of Endocrinology 73 91-98

Munson PJ and Rodbard D (1980) LIGAND: a versatile computerized approach for the characterization of ligand binding systems Analyfical Biochemistry 107 220-239
Ottobre JS, Lewis GS, Thayne WV and Inskeep EK (1980) Mechanism by which progesterone shortens the estrous cycle of the ewe Biology of Reproduction 23 1046-1053

Rosenfeld CS, Yuan X, Manikkam M, Calder MD, Garverick HA and Lubahn DB (1998) Sequencing, cloning, and localisation of bovine estrogen receptor-beta (ER $\beta)$ in the reproductive tract of the cow Biology of Reproduction 58 Supplement 1120

Salamonsen LA, Chemy RA and Findlay JK (1992) Studies in vitro of effects of steroid hormones and the blastocyst on endometrial function in the sheep Reproduction Fertility and Development 4 275-281

Scatchard G (1949) The attraction of proteins for small molecules and ions Annals of New York Academy of Sciences 51 660-672

Spencer TE and Bazer FW (1995) Temporal and spatial regulation of uterine receptors for oestrogen and progesterone during the estrous cycle and early pregnancy in ewes Biology of Reproduction 53 1527-1544

Spencer TE, Becker WC, George P, Mirande MA, Ogle TF and Bazer FW (1995) Ovine interferon- $\tau$ regulates expression of endometrial receptors for estrogen and oxytocin but not progesterone Biology of Reproduction 53 732-745

Spencer TE, Mirando MA, Mayes JS, Watson GH, Ott TL and Bazer FW (1996) Effects of interferon- $\tau$ and progesterone on oestrogen-stimulated expression of receptors for oestrogen, progesterone and oxytocin in the endometrium of ovariectomized ewes Reproduction Fertility and Development 8 843-853

Stone GM, Murphey L and Miller BG (1978) Hormone receptor levels and metabolic activity in the uterus of the ewe: regulation by oestradiol and progesterone Australian Journal of Biological Science 31 395-403

Sumida C and Pasqualini JR (1979) Determinaton of cytosol and nuclear estradiol-binding sites in fetal pig uterus by $\left[{ }^{3} \mathrm{H}\right]$ estradiol exchange Endocrinology 105 406-413

Sumida C, Lecerf F and Pasqualini JR (1988) Control of progesterone receptors in fetal uterine cells in culture: effects of estradiol, progestins, antiestrogens, and grow th factors Endocrinology 122 3-11

Tseng L and Zhu HH (1997) Regulation of progesterone receptor messenger ribonucleic acid by progestin in human endometrial stromal cells Biology of Reproduction 57 1360-1366

Vesanan M, Isomaa V, Alanko M and Vihko R (1991) Bovine uterine, cervical and ovarian estrogen and progesterone receptor concentrations Animal Reproduction Science 26 61-71

Vesanen M, Isomaa $V$ and Vihko $R$ (1988) Cytosol estrogen and progesterone receptors in bovine endometrium after uterine involution postpartum and in the estrous cycle Animal Reproduction Science 17 9-20

Wathes DC and Hamon M (1993) Localization of oestradiol, progesterone and oxytocin receptors in the uterus during the oestrous cycle and early pregnancy of the ewe Journal of Endocrinology 138 479-491

Wathes DC and Lamming GE (1995) The oxytocin receptor, luteolysis and the maintenance of pregnancy Journal of Reproduction and Fertility Supplement 49 $53-67$

Wathes DC, Mann GE, Payne JJ, Riley PR, Stevenson KR and Lamming GE (1996) Regulation of oxytocin, oestradiol and progesterone receptor concentrations in different uterine regions by oestradiol, progesterone and oxytocin in ovariectomized ewes Journal of Endocrinology 151 375-393

Woody CO and Ginther OJ (1968) Effect of exogenous progesterone on corpora lutea in unilaterally hysterectomized heifers Journal of Animal Science 27 1387-1390

Xiao CW and Goff AK (1998) Differential effects of oestradiol and progesterone on proliferation and morphology of cultured bovine uterine epithelial and stromal cells journal of Reproduction and Fertility 112 315-324

Zelinski MB, Hirota NA, Keenan EJ and Stormshak F (1980) Influence of exogenous estradiol-17 $\beta$ on endometrial progesterone and estrogen receptors during the luteal phase of the ovine estrous cycle Biology of Reproduction 23 743-751

Zelinski MB, Noel B, Weber DW and Stomshak F (1982) Characterization of cytoplasmic progesterone receptors in the bovine endometrium during proestrus and diestrus Journal of Animal Science 55 376-383

Zollers WG, Garverick HA, Smith MF and Moffatt RJ (1993) Concentrations of progesterone and oxytocin receptors in endometrium of postpartum cows expected to have a short or normal oestrous cycle journal of Reproduction and Fertility $97329-337$ 